\title{
Gram per Capsule
}

National Cancer Institute

\section{Source}

National Cancer Institute. Gram per Capsule. NCI Thesaurus. Code C73719.

A capsule dosing unit expressed in gram(s) per capsule. 